\title{
Jacques Tixier (1925-2018)
}

\author{
Marie-Louise Inizan, Hélène Roche
}

UMR 7055, CNRS, Université Paris Nanterre, France. Email: Inizan: inizan@ wanadoo.fr;

Roche: helene.roche957@orange.fr

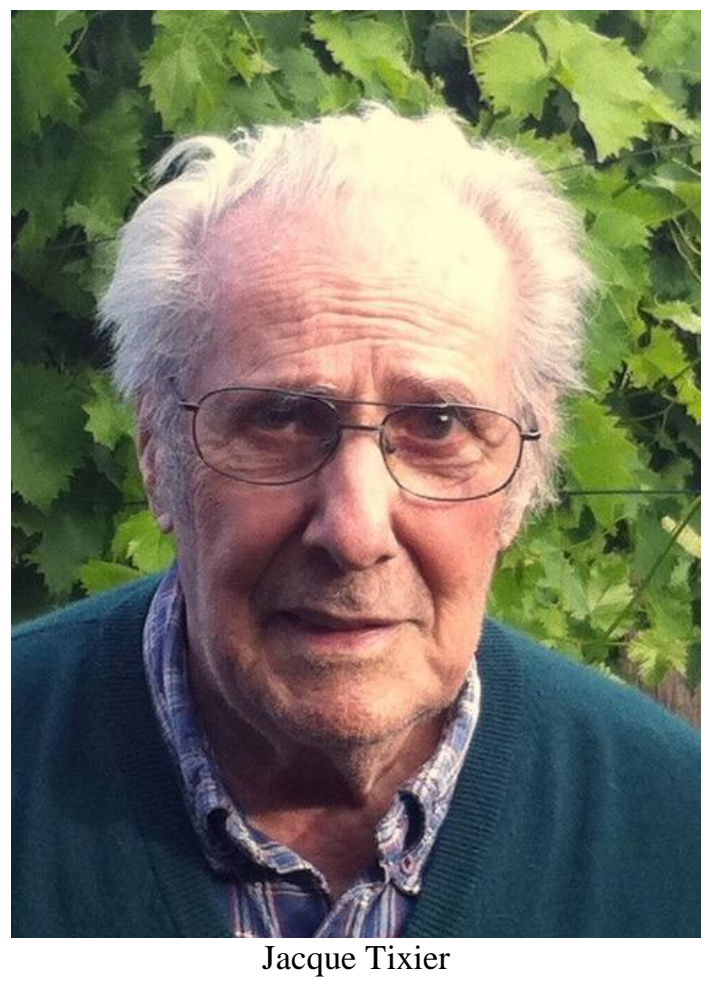

Jacques Tixier was an internationally known prehistorian and the founder of the technological "reading" of lithic industries. The first approach to this interpretation is based on experiments and the recognition of the chronological order of technical gestures.

He passionately sought out his study material in the field and conducted excavations in France, North Africa, the Near East and the Middle East. He was driven by the need to transmit his knowledge and was an excellent orator and teacher. His strong character, warmth and contagious enthusiasm captured the attention of novice students, seasoned professionals and reached out to the general public, both old and young.

His extremely rich career, with several ruptures, is not easy to sum up. We will attempt to present the main stages of this career, then develop several of the "themes" that best reflect his personality and his most important scientific contributions to Prehistory.

Published by the School of History, Classics and Archaeology, University of Edinburgh ISSN: 2055-0472. URL: http://journals.ed.ac.uk/lithicstudies/

Except where otherwise noted, this work is licensed under a CC BY 4.0 licence. 


\section{The Algerian period}

Jacques Tixier was born on the first of January 1925 in Bordeaux, and entered the Primary Teachers Training School (Ecole Normale d'Instituteurs) of Algiers-Bouzaréah in 1947. In 1948, he was appointed to a school in El-Hamel, a village on the border of the northern Algerian Sahara. He had excellent memories of his teaching years and loved talking about them. Considering his gift for teaching, we can easily imagine that his young pupils must also cherish good memories of their master. He discovered a prehistoric site near his school (which he simply called "El Hamel"), comprising several Epipalaeolithic and Neolithic levels, and abundant microliths. After school, he collected material from the surface, excavated, sieved, marked and studied lithic material, day in, day out. In this solitary environment, he took to knapping, in order to understand the series he discovered. He subsequently joined the Bardo Museum, directed by Professor Lionel Balout, Dean of the Arts Faculty of Algiers. The latter was struck by Tixier's remarkable qualities of observation and first of all involved him in the preparation of the $2^{\text {nd }}$ Panafrican congress of Prehistory in Algiers (1952) - where his first publication appeared (Tixier 1954) (These references refer to J. Tixier's general bibliography; the other references are listed at the end of the text.) - then transferred him to Algiers (1953). Jacques Tixier returned to his studies (he obtained a Certificate of prehistoric archaeology of North Africa) and was responsible for the reorganization of many of the prehistory collections curated at the Bardo Museum, many of which were incorporated into his $\mathrm{PhD}$ thesis., and the installation of the Centre for Anthropological, Prehistoric and Ethnological Research (Centre de Recherches Anthropologiques, Préhistoriques et Ethnologiques - CRAPE). He excavated the Dakhlet esSaadane rock shelter during this period, which he published in 1955 (Tixier 1955a). That same year, he moved away from school teaching and began working in the CNRS, where he remained throughout his career.

When fieldwork in Algeria was no longer possible (due to the Algerian War 1954-1962), he began working in Morocco in 1957, where he studied the industries of Aïn Fritissa, which were published two years later (Tixier 1959a). He came back to France during the summer holidays and excavated, knapped and conversed with François Bordes. He assimilated the new methods - including statistical methods which were developing at that time. He also began a PhD directed by L. Balout, on the Epipalaeolithic of Maghreb.

\section{Back to France}

In 1962 he was obliged to leave Algeria. He was attached to the Chair of Prehistory of the National Museum of Natural History, which had just been created for the Dean L. Balout, at the same time as the associated CNRS laboratory (ERA 50, then LA 184). These structures were hosted at the imposing Human Paleontology Institute building (IPH, Monaco Foundation, associated with the MNHN), rue René Panhard, in the $13^{\text {th }}$ arrondissement of Paris.

He submitted his PhD in Bordeaux in 1963. This "Typology of the Epipaleolithic of Maghreb" (Tixier 1963a) went well beyond the scope of Maghreb and became a widely diffused "classic". Indeed, the description of the types can be applied to different microlithic industries- geometrical or not - and the terminology adopted in the $\mathrm{PhD}$ is universal. (His terminological lexicon also inspired the lexicon in "Prehistory of knapped stones", vol. 2 (Tixier 1984a).)

Alongside his teaching and research activities, he became involved in two prehistoric divisions of the Ministry for Culture - Lorraine then Limousin - and was elected to the National CNRS committee twice (section 31). 
Throughout his career, J. Tixier made countless interventions for a very diverse public, and was internationally recognized early on as a top level knapper-experimenter. In 1973, his friend Philip Smith (Professor at the University of Montreal) instigated his involvement in a special edition of Time Life on "Cro-Magnon" (Tixier 1973a), for which the photographer Pierre Boulat took a magnificent series of photos of J. Tixier knapping and manufacturing bone tools.

\section{His main fieldwork}

In 1964, he began excavations at La Faurélie II (Magdalenian and Azilian) in Dordogne (which finished in 1972). Many French and foreign students participated in fieldwork at the site and learned a lot from their time there, as J. Tixier, a born teacher, enjoyed sharing his knowledge and bringing them to visit the many other excavations of the region at the end of the week. 1964 was also the year of the Eyzies Congress, which was unfortunately never published, but where he met the American Don E. Crabtree, another pioneering technologist, who became a very good friend. Crabtree introduced J. Tixier to pressure flaking, which was a complete revelation to him. He discovered Amerindian obsidian pressure flaking with Crabtree's first experiments with a crutch and copper point, which immediately evoked for him the flint blade debitage he had observed in Capsian and Neolithic assemblages in North Africa. He also discovered the intentional heating of raw materials to optimize their properties. He began a series of heating experiments at the IPH in 1966, which were subsequently revived and published in 1976 (Inizan et al. 1976a).

In 1967 and 1969, with Roger de Bayle des Hermens (CNRS), he undertook two fieldwork seasons at Jebel Irhoud in Morocco, where he recorded the stratigraphy, collected the lithic series and found a juvenile human humerus (Hublin et al. 1987).

In 1968, the Museum signed a convention to take over research at Ksar Aqil in Lebanon. This vast rock shelter is located in the valley of Antelias and was settled from the Middle Palaeolithic to the Epipalaeolithic. The 22-m-deep stratigraphy reveals continuous occupation from the base to the summit. Professor L. Balout entrusted Jacques Tixier with the direction of this enormous Palaeolithic site and excavations there began in 1969. By that time, he was part of the RCP 50 CNRS team, directed by Jean Perrot. He obtained a Wenner Gren Foundation grant which enabled many young North American and European students to work there. Again, J. Tixier gave lessons on prehistoric technology (often by knapping) and when possible, brought his excavators to discover the other accessible sites of the region.

But in 1975 the excavation season at Ksar Akil was brutally interrupted by the beginning of the civil war in Lebanon (1975-1990). Yet, that same year, J. Tixier was invited to the inauguration of the National Museum of Qatar, at the instigation of the Danish prehistorian Holger Kapel, who needed a specialist to confirm the alleged Early Palaeolithic age of the bifaces that he had discovered at prehistoric sites. Based on knapping techniques, the early age of these bifaces was not confirmed, but a long friendship nonetheless ensued between the two men. And this was the beginning of another adventure for Jacques Tixier. In 1976, a contract was signed between the CNRS and the Emirate of Qatar and six multidisciplinary archaeological fieldwork seasons took place from 1976 to 1982, as part of the RCP 476, which was created by the CNRS for this purpose, and with the support of the Ministry for Foreign Affairs.

\section{The creation of the Prehistory and Technology laboratory}

In 1978, J. Tixier submitted a State Thesis, spurred on by Professor Eric de Dampierre, the director of the Department of Ethnology and Comparative Sociology at Paris X-Nanterre at that time, who wished to consolidate the teaching of prehistory. This enabled J. Tixier to 
supervise his students' PhDs, of which there were many. (Hélène Roche who submitted her PhD in 1979 was the last of his students who was not supervised by him (only on paper of course).) Furthermore, until that time, his team was mainly comprised of young researchers and $\mathrm{PhD}$ students - including the authors of this text - and was part of the LA 184. But following disagreements with Professor Balout, who was organizing his own succession at that time, he was brutally evicted from the IPH, with his team. And that is how the CNRS came to propose the creation of his own laboratory in the Centre for Archaeological Research (Centre de Recherche Archéologique - CRA): URA 28 "Prehistory and Technology", a thematic laboratory, with no geographic borders or temporal limits, created in 1979. From 1981 onwards, the team had two bases; one in Sophia Antipolis (at the site of the CRA) and the other at the CNRS in Meudon-Bellevue. As a result, he was offered offices in a building known as "the factory", which had previously been an engine-testing site. The building was still in its original state but with some CNRS funds and a lot of bright colours, the offices were soon rendered suitable. Up until 1988, the laboratory was comprised solely of lithic specialists, but decided to open out to specialists of other materials after that date (bone, pottery, and later metal). Jacques Tixier directed the laboratory - which subsequently became ERA 28 - until 1987. (Since 1997, the laboratory is implanted in the Maison de l'Archéologie et de l'Ethnologie on the Nanterre campus and was reorganized in 1999 into a Mixed Research Unit - Unité Mixte de Recherches (UMR 7055, CNRS/ Paris Nanterre University) and is now called «PréTech».)

\section{From typology to the technological approach}

"... a constant preoccupation guides him: the intelligence of knapping and retouch techniques -the forms and types of lithic industries" wrote L. Balout in the preface of "Typologie de 1'Epipaléolithique du Maghreb" (Tixier 1963b: 5). This intelligence of knapping techniques, which leads to forms and types, is clearly discernible in his remarkable cleaver classification as early as 1956 (Tixier 1957), which is still a model of its kind today.

"How" tools were made was J. Tixier's first concern, much more so than "why", which he considered to be a different, and much more elusive problem for understanding prehistoric populations. On the other hand, he soon realised that the "how" question could be tackled through observation and reasoned experimentation, in order to elucidate all the knapping processes, long before formalising technological interpretation. He developed his analysis principles for a lithic complex for the first time during a colloquium organized by the Wenner Gren Foundation in 1965 and subsequently published a reputed article (Tixier 1967).

But all these developments were still a long way off when Jacques Tixier began his career at the beginning of the 1950s. The "typological revolution" had just started, with the application of type-lists - and cumulative diagrams, initiated by François Bordes for the Early and Middle Palaeolithic (Bordes 1950) and Denise de Sonneville-Bordes and Jean Perrot (1953) for the Upper Palaeolithic. These study methods were very beneficial for prehistory as they brought order and rigour to the study of lithic industries, which were sometimes lacking in descriptions. J. Tixier himself contributed to the typological domain in a number of his early publications, although it was already clear that technology was his main preoccupation.

But excesses of all kinds can have adverse effects and at the end of the 60s and early 70s, J. Tixier and a number of his colleagues were struck by the "dehumanisation" of studies and publications on knapped lithic productions, which were often only typologies, percentages and diagrams. Everything was ready for another revolution, a technological one this time, and his whole analytical approach to lithic industries, including the capital notion of the chaine opératoire, theorized by Marcel Mauss and André Leroi Gourhan, was to be part of it. His first summary of this appeared in his thesis "Method for the study of lithic tooklits - Méthode 
pour l'étude des outillages lithiques" submitted in 1978. Surprisingly, this volume was not officially published at the time, but was nonetheless widely read. It was only published in 2012, in a magnificent bilingual edition, printed in Luxemburg (Tixier 2012) and apart from some inevitable hints of obsolescence over 30 years later, the work as a whole is still extremely pertinent.

Several meetings and round tables subsequently led to exchanges, debates (sometimes heated) and consolidated and diffused this new approach. The first of these was a round table organized by the newly created URA 28, in 1979, at the CRA in Sophia Antipolis (Préhistoire et technologie lithique, 1979). A second one followed a year later in Tervuren, Belgium, entitled "Tailler! Pour quoi faire ?" (Cahen 1982). Quite a program. A third colloquium focusing on blade and pressure debitage, was organized by the URA 28 in our premises in Meudon-Bellevue in 1982 and was published by the CREP (Centre de Recherches et d'Etudes Préhistoriques - Centre of Research and Prehistoric Studies) as volume 2 of the series "Préhistoire de la pierre taillée" (Title inspired by André Leroi-Gourhan's "Prehistory of Western art - Préhistoire de l'art occidental" (Leroi-Gourhan 1978), who generously authorized us to borrow it.) (1984a). The highly successful volume 1 "Technologie et terminologie", which partly presented his technological approach had been published several years beforehand, in 1980 (Tixier et al. 1980).

\section{The CREP venture, or Jacques Tixier's idea of patronage}

In November 1965, the French Petrol Company (Compagnie Française des Pétroles Algeria) invited him to conduct fieldwork in the region of Ouargla, during the course of which he discovered the site of Bordj Mellala with Dr Trécolle. The site had been protected by a dune up until then and was perfectly intact. The CFP(A) funded work at the site for the next two years, then the site publication in 1978 (Tixier 1978a 1978b). The original format and remarkable iconography of this publication received much attention, in particular from Yvonne Rebeyrol, a scientific journalist at le Monde, who highlighted the quality of this site monograph. It was published by the CREP, a non-profit making association created for this purpose. At that time, Jacques Tixier was the editorial advisor for Encyclopaedia Universalis, for which he was paid. He decided to transfer all of these earnings to the CREP. In this way, when volume 1 of the "Préhistoire de la pierre taillée" series was ready (For the anecdote, when the text of the volume was ready for publication and we were at the design and layout stage, we no longer had access to the IPH offices. Yet, in that pre-computer era, we needed a lot of space. Yves Coppens, who was the director of the Musée de l'Homme at that time, kindly hosted us in the Anthropology laboratory.) (Tixier et al. 1980a), we were able to publish it without any problems under the CREP label. Not only did Tixier's initial generosity give us considerable freedom of publication, it also enabled us to set a sale price in keeping with the budgets of those for whom it was chiefly intended, i.e., students. And the venture did not stop there, as profits from the sale of volume 1 were then used to publish volume 2 (proceedings of the round table on blade debitage, (1984a)), then volume 3 (Inizan et al. 1992), the English version of volume 1, revised and augmented of a multilingual lexicon (German, English, Arabic, French, Greek, Italian, Russian, Spanish, Portuguese) at the end of the volume, and finally volumes 4 (Inizan et al. 1995) and 5 (Inizan et al. 1999), which are reeditions of volumes 1 and 3, with two additional chapters. We also transferred the rights for the text of vol. 4 -or vol. 5- for translation into Japanese, Portuguese and Farsi, and then published them online with free access in 2009 (see references at the end of the article). 


\section{Teaching, transmitting, exchanging}

Tixier's lab at the IPH was beneath the glass roof and was the brightest part of that prestigious but rather austere building (we had the impression that we were on our way to "heaven"). There were several small rooms behind his office, one of which was his knapping workshop with his experimental collections. If you needed to know what a microburin was, several gestures later, there you had it and understood perfectly. A burin spall? Easy... and no more mixing up crested bladelets and backed bladelets!

Many French and foreign prehistorians came to meet him, some for a short visit and for the pleasure of conversing with him, others from countries where prehistory teaching was still not very developed, who came to learn from him and stayed a while.

From 1963 onwards, J. Tixier set up informal Prehistory courses, which people heard about by word of mouth. These inspiring courses were held in a large room in the IPH basement, which was a lot darker than his office. Even at that time, they already focused more on "how" tools were made than on the often-fastidious description of "types" of objects (Any students in prehistoric archaeology at the end of the "60s who did not have to "ingurgitate" endless lists of Bronze Age daggers or Villanovian fibulae, for example, can cast the first stone!), and incorporated different materials (stone, metal, bone, etc.), unlike in other more conventional prehistoric archaeology courses. In Tixier's courses, we were not shown slides or drawings but real stones, knapped before our eyes. The public was mixed and included confirmed professionals, students, and prehistory-loving amateurs who excavated and were well versed in typology. Questions arose from swirls of tobacco smoke from all quarters, including from Tixier (it was a different epoch).

This teaching was set up informally on an unpaid basis, and was later institutionalised at the IPH as part of the Practical School for Higher Studies - Ecole Pratique des Hautes Etudes, then in Nanterre from 1972 onwards, with a firm technological focus. And it was no mean feat to introduce flint knapping to University lecture halls. We were responsible for the practical courses and it soon became clear to the three of us that the students had trouble with the terminological typological and technological jungle. We therefore felt the need to create a standardized vocabulary to enhance mutual understanding and back up the technological interpretation of knapped lithic objects. This resulted in the publication of the first volume of the series "Préhistoire de la pierre taillée - (Prehistory of knapped stone)", edited by the CREP in (Tixier et al. 1980).

The teaching program at the IPH, then Nanterre, was not the only place to learn and exchange: as we said earlier, there were excavations (La Faurélie, Ksar Akil, etc.), round tables, but also daily conversations, and when visitors to the lab came to talk about a specific problem, students often listened in and learnt from the exchange too, as they were no hierarchical barriers.

In this way, J. Tixier trained several generations of technologists. And when, over 30 years ago, the CNRS developed permanent teaching courses, it also set up a "knapping course" as part of the professional teaching program. The first session was so successful that this teaching course became a permanent element, and was subsequently taught by the trained generation. It is now part of the Thematic Schools and continues to attract students from across the world, and will no doubt soon be taught by the third generation... 


\section{References apart from those cited in the bibliography of Jacques Tixier}

Bordes, F. 1950, Principes dune méthode detude des techniques de débitage et de la typologie du Paleolithique ancien et moyen. L'Anthropologie, 54(1): 19-34.

Boulat, P., (photographer) 1973, Toolmaking: A Modern Master Demonstrates the Ancient Art. In: Cro-Magnon Man (Prideaux, T., Ed.). The Emergence of Man, Time Life Books, New York: p. 83-91.

Cahen, D. (Ed.) 1982, Tailler! Pour quoi faire? Préhistoire et technologie lithique II. Recent progress in microwear studies, Studia Praehistorica Belgica Vol. 2. Koninklijk Museum voor Midden-Afrika, Musée royal de l'Afrique centrale, Tervuren, $328 \mathrm{p}$.

Leroi-Gourhan, A. 1978, Préhistoire de l'Art Occidental. Art et les Grandes Civilisations. Éditions d'Art Lucien Mazenod, Paris, 499 p.

de Sonneville-Bordes, D. \& Perrot, J. 1953, Essai d'adaptation des méthodes statistiques au Paléolithique supérieur. Premiers résultats. Bulletin de la Société préhistorique de France, 50(5): 323-333. doi:10.3406/bspf.1953.3059

\section{References}

Tixier, J. 1954, Le gisement préhistorique d'El-Hamel. Libyca. Anthropologie et archéologie préhistoriques, 2: 79-120.

Tixier, J. 1955, Un biface acheuléen dans le Sahel d'Alger. Bulletin de la Société Historique Naturelle d'Afrique du Nord, 46: 277-279.

Tixier, J. 1955, Un gisement préhistorique « in situ » au sud de Bou-Saâda. In: Congrès panafricain de préhistoire : Actes de la 2ème session, Alger 1952 (Balout, L., Ed.), Direction de l'Intérieur et des beaux-Arts - Service des Antiquités / Arts et Métiers graphiques, Alger / Paris: p. 681-684.

Tixier, J. 1955a, Les abris sous roche de Dakhlet es-Saâdane (commune mixte de Bou-Saâda); I, les industries en place de l'abri B. Libyca, 3: 81-128.

Balout, L. \& Tixier, J. 1957, L’Acheuléen de Ternifine. In: Comptes Rendus de la XVe session Congrès préhistorique de France, Poitiers-Angoulême, 15 - 22 Juillet 1956, Société préhistorique française, Paris: p. 214-218.

Tixier, J. 1957, Le hachereau dans l'Acheuléen nord-africain. Notes typologiques. In: Comptes Rendus de la XVe session Congrès préhistorique de France, PoitiersAngoulême, 15 - 22 Juillet 1956, Société préhistorique française, Paris: p. 914-923.

Tixier, J. 1958, Les burins de Noailles de l'Abri André Ragout, Bois-du-Roc, Vilhonneur (Charente). Bulletin de la Société préhistorique de France, 55(10): 628-644. doi:10.3406/bspf.1958.3707

Tixier, J. 1958, Les pièces pédonculées de l'Atérien. In: Bericht über den V. internationalen Kongress für Vor- und Frühgeschichte Hamburg, UISPP, Hamburg: p. 813-817.

Camps, G., Camps, H., Curtès, A., Curtès, E. \& Tixier, J. 1959, Prise de date pour un gisement épipaléolithique et néolithique au Cap Chenoua (Algérie). Libyca, 6-7: 289.

Tixier, J. 1959, Les pièces pédonculées de l'Atérien. Libyca, 6-7: 127-158. 
Tixier, J. 1959, Notes de typologie nord-africaine. I., Recherche des gestes techniques sur un burin exceptionnel. Libyca, 6-7: 199-203.

Tixier, J. 1959a, Les industries lithiques d'Aïn Fritissa (Maroc oriental). Bulletin D’Archéologie Marocaine, 3: 107-244.

Tixier, J. 1960, Examen en laboratoire de la faucille $\mathrm{n}^{\circ} 2$ de Columnata. Libyca, 8: 253-258.

Tixier, J. 1960, Gravure rupestre de Bou-Saâda (Algérie). Bulletin de la Société Royale Belge d'études géologiques et archéologiques, 17: 21-27.

Tixier, J. 1962, Le «Tenéréen» de l'Adrar Bous III. In: Documents scientifiques Missions Berliet Ténéré-Tchad, Arts et Métiers Graphiques, Arts et Métiers Graphiques, Paris: p. 333-348.

Tixier, J. 1963a, Typologie de l'Epipaléolithique du Maghreb. thèse thesis at Université de Bordeaux, Bordeaux.

Tixier, J. 1963b, Typologie de l'Epipaléolithique du Maghreb. Mémoires du Centre de recherches anthropologiques préhistoriques et ethnographiques Vol. 2. Arts et métiers graphiques, Alger, Paris, 209 p.

Tixier, J. 1965, L'industrie capsienne d'Aïn Zannouch (Tunisie). In: Compte-rendu de la XVIème session : Principauté de Monaco, 28 août-5 septembre 1959, Société préhistorique française, Paris: p. 1027-1044.

Tixier, J. 1966, Fiches typologiques africaines, ler cahier, fiches 1-32, Epipaléolithique du Maghreb, types 1-25. (report), Muséum national d'histoire naturelle, Paris.

Tixier, J. 1966, Fiches typologiques africaines. 1er cahier, fiches 1-32, Epipaléolithique du Maghreb, types 1-25. Congrès panafricain de préhistoire et d'études quaternaires. Arts et métiers graphiques; Muséum national d'histoire naturelle, Paris, $32 \mathrm{p}$.

Tixier, J. 1966, Ouargla, découvertes préhistoriques. Compagnie Française des Pétroles (Algérie). Actualités, 25: 4.

Tixier, J. 1966, Têtes de flèches néolithiques appointées par la technique du coup de burin. L'Anthropologie, 70: 541-544.

Balout, L., Biberson, P. \& Tixier, J. 1967, L’Acheuléen de Ternifine (Algérie), Gisement de l'Atlanthrope. L'Anthropologie, 71: 217-238.

Bayle, R. \& Tixier, J. 1967, Le gisement kérémien de la Jumenterie de Chaouchaoua, Tiaret, Algérie. In: VIe Congrès Panafricain de Préhistoire, Dakar: p. 288-293.

Méry, A. \& Tixier, J. (1967). La station préhistorique d'Aïn-Chebli, region de Reggan (Sahara algérien). presented at the VIe Congrès Panafricain de Préhistoire, Dakar.

Tixier, J. 1967, Fiches typologiques africaines, 3ème cahier, fiches 65-96, Pièces pédonculées atériennes du Maghreb et du Sahara, types 1-30. (report), Muséum national d'histoire naturelle, Paris.

Tixier, J. 1967, Fiches typologiques africaines. 3ème cahier, fiches 65-96, Pièces pédonculées atériennes du Maghreb et du Sahara, types 1-30. Congrès panafricain de préhistoire et d'études quaternaires. Arts et métiers graphiques; Museum national d'Histoire naturelle, Paris, $32 \mathrm{p}$. 
Tixier, J., (director), 1967, La taille des silex. Office Français des Techniques Modernes d'Éducation, Institut Pédagogique National, Paris. $8 \mathrm{~mm}$ colour film. Running time: 3 minutes.

Tixier, J., (director), 1967, Les plus vieux silex taillés. Office Français des Techniques Modernes d'Éducation, Institut Pédagogique National, Paris. $8 \mathrm{~mm}$ colour film. Running time: 3 minutes.

Tixier, J. 1967, Procédés d'analyse et questions de terminologie concernant l'étude des ensembles industriels du Paléolithique récent et de l'Épipaléolithique dans l'Afrique du Nord-Ouest. In: Background to evolution in Africa. Proceedings of a Symposium held at Burg Wartenstein Austria, July-August, 1965 (Bishop, W.W. \& Clark, J.D., Eds.), University of Chicago Press, Chichago: p. 771-820.

Mercier, B. \& Tixier, J., (directors) 1968, Outils préhistoriques. À la recherche des techniques de taille. Office Français des Techniques Modernes d'Éducation, Institut Pédagogique National, Paris. 16 or $35 \mathrm{~mm}$ film. Running time: 20 minutes. (in French and English versions)

Tixier, J. 1968, Lorraine. Gallia Préhistoire, 11(2): 343-352. doi:10.3406/galip.1968.1326

Tixier, J. 1968, Notes sur le Capsien typique. In: La préhistoire. Problèmes et tendances, Centre national de la recherche scientifique (C.N.R.S.), Paris: p. 439-451.

Barrière, C., Daniel, R., Delporte, H., Escalon de Fonton, M., Parent, R., Roche, J., Rozoy, J.G., Tixier, J. \& Vignard, E. 1969, Epipaléolithique-Mésolithique. Les microlithes géométriques. Bulletin de la Société préhistorique française. Études et travaux, 66(1): 355-366. doi:10.3406/bspf.1969.4190

Tixier, J. 1970, Compte-rendu. de V. Gábori-Csánk: la station du Paléolithique moyen d'Erd.Hongrie. Acta Archoeologica Scientiarum Hungarica, 22: 420-424.

Tixier, J. 1970, L'abri sous roche de Ksar'Aqil. La campagne de fouilles 1969. Bulletin du Musée de Beyrouth, 23: 173-191.

Tixier, J. 1971, Les apports de la stratigraphie et de la typologie au problème des origines de l'homme moderne dans le Maghreb. In: Origine de l'homme moderne (Bordes, F., Ed.). Écologie et Conservation Vol. 3, U.N.E.S.C.O., Paris: p. 121-127.

de Bayle des Hermens, R. \& Tixier, J. 1972, Le gisement kérémien de la Jumenterie de Chaouchaoua, Tiaret, Algérie. In: Congrès panafricain de Préhistoire et d'Étude du Quaternaire: Actes de la 6ème session, Dakar 1967 (Hugot, H.-J., Ed.), Chambéry, Imprimeries Réunies, Dakar: p. 288-293.

Méry, A. \& Tixier, J. 1972, La station préhistorique d'Aïn-Chebli, région de Reggan (Sahara algérien). In: Congrès panafricain de Préhistoire et d'Étude du Quaternaire : Actes de la 6ème session, Dakar 1967 (Hugot, H.-J., Ed.), Chambéry, Imprimeries Réunies, Dakar: p. 109-110.

Tixier, J. 1972, Obtention de lames par débitage « sous le pied ». Bulletin de la Société préhistorique française. Comptes rendus des séances mensuelles, 69(5): 134-139. doi:10.3406/bspf.1972.4365

Tixier, J. 1973, Lorraine. Gallia Préhistoire, 16(2): 439-461.

URL: https://www.persee.fr/doc/galip_0016-4127_1973_num_16_2_1455 
Tixier, J. 1973, Note de typologie Nord-Africaine, II : une pointe «marocaine » inédite. In: Estudios dedicados al Profesor Dr. Luis Pericot. Instituto de Arqueolgia y prehistoria publicaciones Eventuales Vol. 23, Universidad de Barcelona, Instituto de Arqueología y Prehistoria, Barcelona: p. 47-49.

Tixier, J. \& Guérin, P., (directors) 1973, La vie quotidienne des hommes préhistoriques. École Moderne, Mouans-Sartoux. double sided audio record (33 rpm), 12 illustrated slides. Running time: 20 minutes. URL: http://www.icemfreinet.net/ btj/H429preh/outiprson2.htm

Tixier, J. 1973a, Toolmaking: A Modern Master Demonstrates the Ancient Art. In: CroMagnon Man (Prideaux, T., Ed.). The Emergence of Man, Time Life Books, New York: p. 83-91.

Tixier, J. 1974, Fouille à Ksar'Aqil, Liban (1969-1974). Paléorient, 2(1): 183-185. doi:10.3406/paleo.1974.4182

Tixier, J. 1974, Glossary for the description of stone tools with special referance to the Épipalaeolithic of the Maghreb. (Translation by M.H. Newcomer). Newsletter of lithic technology: Special publication, 1: 36.

Tixier, J. 1974, Microburins du Magdalénien V à la Faurélie II (Dordogne). L'Anthropologie, 78: 189-196.

Tixier, J. 1974, Poinçon décoré du Paléolithique supérieur à Ksar' Aqil (Liban). Paléorient, 2(1): 187-192. doi:10.3406/paleo.1974.4183

Balout, L., Chavaillon, J., Coppens, Y. \& Tixier, J. 1975, L'Afrique, berceau de l'humanité ? In: Une histoire de l'Afrique est-elle possible? Les Nouvelles Éditions africaines (Amengual, M. \& Aguessy, H., Eds.), Abidjan, Dakar: p. 51-85.

Tixier, J. 1975, Le site paléolithique de Ksar'Aqil. Compte-rendu des séances mensuelles de la Société Préhistorique Française, 72(8): 226-END PAGE.

Tixier, J. 1975, Les techniques de taille. In: Livret-guide exposition « Hommes de la Préhistoire » (Texier, P.-J., Ed.), Crédit Communal de Belgique, Bruxelles: p. 12-14.

Tixier, J. 1975, Limousin. Gallia Préhistoire, 18(2): 601-612. URL: https://www.persee.fr/doc/galip_0016-4127_1975_num_18_2_1510

Tixier, J. 1975, Préhistoire en Moselle, fiche d'information. (report), Association des amis de l'Archéologie mosellane Vol. 1-2, 4-8 p.

Tixier, J. \& et al. (Eds.) 1975, L'Homme et son environnement pendant le Würm en Europe de l'Ouest, Union internationale pour l'étude du Quaternaire. Commission palecology of early man. Compte-rendu d'une réunion du sous-groupe de travail pléistocène supérieur, Ouest de l'Europe, organisée par J.-M. le Tensorer, Université de Bordeaux III, Maison des Sciences de l'Homme 18-19 avril 1975. Union internationale pour l'étude du Quaternaire, Bordeaux, 65 p.

Mazière, G. \& Tixier, J. 1976, Les civilisations de l'Épipaléolithique et du Mésolithique du Limousin. In: La Préhistoire française, IXe Congrès de l'Union Internationale des Sciences Préhistoriques et Protohistoriques (Guilaine, J., Ed.), C.N.R.S., Paris: p. 14411446.

Mazière, G. \& Tixier, J. 1976, Les civilisations du Paléolithique supérieur en Limousin. In: La Préhistoire française, IXe Congrès de l'Union Internationale des Sciences Préhistoriques et Protohistoriques (Guilaine, J., Ed.), C.N.R.S., Paris: p. 1280-1296. 
Tixier, J. 1976, Compte-rendu de: Henriette Camps-Fabrer. Un gisement capsien de faciès sétifien, Medjez, II. El-Eulma (Algérie). Études d'Antiquités Africaines.

L'Anthropologie, 80: 526-531.

Tixier, J. 1976, French archaeological mission to Qatar. First campaign. C.N.R.S., R.C.P. 362, Paris. Ministry of Information. Doha, 27 p. (in Arabic)

Tixier, J. 1976, [title in Japanese] Obtention de lames par débitage « sous le pied ».

月刊考古学ジャーナル (Gekkan kōkogaku jānaru - The Archaeological Journal), 120: 11-16. (in Japanese)

Tixier, J. 1976, L'abri sous roche de la Faurélie II. Commune de Mauzens-Miremont. . In: Livret-guide de l'excursion A4, IXe session du Congrès de l'Union Internationale des Sciences Préhistoriques et Protohistoriques, C.N.R.S., Paris: p. 113-116.

Tixier, J. 1976, La Faurélie II. In: Les civilisations de l'Épipaléolithique en Périgord. La Préhistoire française, IXe Congrès de l'Union Internationale des Sciences Préhistoriques et Protohistoriques (Célérier, G., Ed.), C.N.R.S., Paris: p. 1427-1429.

Tixier, J. 1976, L'industrie lithique capsienne de l'Aïn Dokkara. Région de Tébessa, Algérie. Fouilles L. Balout. Libyca, 24: 21-53.

Tixier, J., Marmier, F. \& Trécolle, G. 1976, Le campement préhistorique de Bordj Mellala, Ouargla, Algérie. Cercle de Recherches et d'Études Préhistoriques, Paris, 61 p.

Inizan, M.-L., Roche, H. \& Tixier, J. 1976a, Avantages d'un traitement thermique pour la taille des roches siliceuses. Quaternaria, 19: 1-18.

Bayle des Hermens, R.d. \& Tixier, J. 1977, Pointe pédonculée atérienne découverte à Bordj Chambi (Tunisie). L'Anthropologie, 81: 631-634.

Tixier, J. 1977, Limousin. Gallia Préhistoire, 20(2): 493-516. URL: https://www.persee.fr/doc/galip_0016-4127_1977_num_20_2_1574

Tixier, J. 1977, [title in Arabic] French archaeological mission to Qatar. First campaign 1976. Vol. 1 (translated by Ajjan, L.). Centre national de la recherche scientifique (C.N.R.S.), Recherches anthropologiques au Proche et Moyen Orient, R.C.P. 362, Paris. Ministry of Information, والآث ار ال سد ياحة مدي ريدة .ق طر (Department of Tourism and Antiquities), Doha, 27 p. (in Arabic) ("French archaeological mission to Qatar. First campaign 1976")

Inizan, M.-L. \& Tixier, J. 1978, Outrepassage intentionnel sur pièces bifaciales néolithiques du Qatar (golfe arabo-persique). Quaternaria, 20: 29-39.

Tixier, J. 1978, Archéologie de sauvetage en Afrique. In: Les recherches archéologiques dans les États d'Afrique au Sud du Sahara et à Madagascar, C.N.R.S., Centre régional de frappe de Sophia-Antipolis, Valbonne: p. 151-152.

Tixier, J. 1978, La mission archéologique française à Qatar. In: L'archéologie de l'Iraq du début de l'époque néolithique à 333 avant notre ère. Perspectives et limites de l'interprétation anthropologique des documents. Colloques internationaux du Centre national de la recherche scientifique Vol. 580, C.N.R.S, Paris: p. 207-208.

Tixier, J. 1978, Méthode pour l'étude des outillages lithiques : notice sur les travaux. doctorat thesis at Université Paris Nanterre, Paris, 117 p.

Tixier, J. 1978a, Bordj Mellala, un campement préhistorique au Sahara algérien. In: Universalia (Encyclopadia Universalis), Encyclopædia Universalis, Paris: p. 191-193. 
Tixier, J. 1978b, Bordj Mellala. Eine prähistorische Siedlung in der algerischen Wüste. In: Sahara: 10,000 jahre zwischen Weich und Wüste, Ausstellungskatalog, Museen der Stadt, Cologne: p. 177-180.

Marmier, F., Tixier, J. \& Trécolle, G. 1979, Étude de l'industrie du gisement d'HassiMouillah, région de Ouargla - Sahara algérien III: l'industrie lithique néolithique. Libyca, 26-27: 81-115.

Tixier, J. 1979, Expérience de taille de flèches à tranchant transversal du type de l'Abri JeanCros. In: l'Abri Jean-Cros, essai d'approche d'un groupe humain du Néolithique ancien dans son environnement (Guilaine, J., Ed.), Centre anthropologique des sociétés rurales, Toulouse: p. 127-129.

Inizan, M.-L. \& Tixier, J. 1980, Modifications possibles de la liste des types épipaléolithiques du Maghreb. In: Actes du 8e Congrès panafricain de Préhistoire et des Études du Quaternaire, Nairobi, 5 au 10 septembre 1977 (Leakey, R.E. \& Ogot, B.A., Eds.), International Louis Leakey memorial Institute for african prehistory, Nairobi: p. 25-26.

Rigaud, J.-P. \& Tixier, J. 1980, Préhistoire, méthodologie. In: Encyclopaedia Universalis Vol. 13, Encyclopaedia Universalis, Paris: p. 42-44.

Tixier, J. 1980, La mission archéologique française à Qatar. In: L'archéologie de l'Iraq du début de l'époque néolithique à 333 avant notre ère: Perspectives et limites de l'interprétation anthropologique des documents, Paris, 13-15 juin 1978. Colloques internationaux du Centre national de la recherche scientifique Vol. 580, Centre de Recherches Archéologiques, Valbonne, CNRS - Centre régional de publications de Sophia-Antipolis, Paris: p. 207-208.

Tixier, J. 1980, La mission archeologique francaise a Qatar dirigee par Jacques Tixier 19761977, 1977-1978. Vol. 1. Qatar Ministere de L'information. Department du Tourisme et des Antiquites. Dar Al-Uloom, Doha, 234 p.

Tixier, J. 1980, Préhistoire et technologie lithique : journées du 11-12-13 mai 1979. Publications de l'Unité de Recherches Archéologiques (URA) 28 du Centre de Recherches Archéologiques du C.N.R.S, Cahier Vol. 1. Centre Régional de Publication Sophia Antipolis, Valbonne, 59 p.

Tixier, J. 1980, Préhistoire, la taille expérimentale des roches dures. In: Encyclopadia Universalis, Encyclopædia Universalis, Paris: p. 46-49.

Tixier, J. 1980, Raccords et remontages. In: Préhistoire et technologie lithique : journées du 11-12-13 mai 1979 Publications de 1'Unité de Recherche Archéologique 28, Cahier 1, Centre de Recherches Archéologiques, Valbonne, CNRS - Centre régional de publications de Sophia-Antipolis, Valbonne: p. 50-55.

Tixier, J. 1980, Raccords et remontages. In: Préhistoire et technologie lithique : journées du 11-12-13 mai 1979. Publications de l'URA Vol. 28, Cahier Vol. 1, Centre de Recherches Archéologiques, Valbonne, CNRS - Centre régional de publications de Sophia-Antipolis, Valbonne: p. 50-55.

Tixier, J., Inizan, M.-L. \& Roche, H. 1980, Terminologie et technologie. Préhistoire de la Pierre Taillée Vol. 1. Cercle de Recherches et d'Études Préhistoriques, Paris, 120 p.

Tixier, J. 1980a, Expériences de taille. In: Préhistoire et technologie lithique : journées du 11 12-13 mai 1979. Publications de l'URA Vol. 28, Cahier Vol. 1, Centre de Recherches Archéologiques, Valbonne, CNRS - Centre régional de publications de SophiaAntipolis, Valbonne: p. 47-49. 
Midant-Reynes, B. \& Tixier, J. 1981, Les gestes de l'artisan égyptien. La Recherche, 120(12): 380-381.

Tixier, J. 1981, Archaeology in Qatar. Total information, 87: 34-36.

Tixier, J. \& Inizan, M.-L. 1981, Ksar'Aqil, stratigraphie et ensembles lithiques dans le Paléolihique supérieur, fouilles 1971-1975. In: Préhistoire du Levant: chronologies et organisation de l'espace depuis les origines jusqu'au VI ${ }^{\circ}$ millénaire (Cauvin, J. \& Sanlaville, P., Eds.). Colloques internationaux du Centre national de la recherche scientifique Vol. 598 (Maison de l'Orient. Lyon 10-14 juin 1980), CNRS, Paris: p. 353367.

Chevalier, J., Inizan, M.-L. \& Tixier, J. 1982, Une Technique de perforation par percussion de perles en cornaline (Larsa, Iraq). Paléorient, 8(2): 55-65. doi:10.3406/paleo.1982.4320

Roche, H. \& Tixier, J. 1982, Les accidents de taille. Studia Prahistorica Belgica, 2: 65-76.

Tixier, J. 1982, Nucléus - pendentif de Suse. Paléorient, 8(2): 109-110. doi:10.3406/paleo.1982.4327

Tixier, J. 1982, Techniques de débitage: osons ne plus affirmer. Studia Prahistorica Belgica, 2: $13-22$.

Aumassip, G., Marmier, F., Tixier, J. \& Trécolle, G. 1983, L'Épipaléolithique nord-saharien: Ouarglien ou Mellalien. Compagnie Française des Pétroles (Algérie), Bordeaux, 82 il. $62 \mathrm{p}$.

Inizan, M.-L. \& Tixier, J. 1983, The lithic material. Sumer, 39(1-2): 62-65.

Inizan, M.-L. \& Tixier, J. 1983, Tell El'Oueili. Le matériel lithique. In: Larsa et Oueili, travaux de 1978-1981 (Huot, J.-L., Ed.). Mémoire (Editions Recherche sur les civilisations) Vol. 26; Bibliotheque de la Delegation Archeologique Francaise en Irak, Vol. 3; Centre de recherches d'archéologie orientale, Université de Paris I, Vol. 4, Éditions Recherche sur les Civilisations, Paris: p. 163-175.

Roche, H. \& Tixier, J. 1984, Tecnologia litica: A questão dos acidentes de lascamento. Resumo. Rivista de Pre-historia. Universidade de São Paulo. Institutto de Pré-historia. Edição comemorativa de cinqüentenario de Universidade de São Paulo, 6: 256.

Tixier, J. 1984, Bordj Mellala - sitio superficial no Norte de Deserto de Saara, Argélia. Resumo. Revista de pré-história - Universidade de São Paulo. Institutto de Préhistoria, 6(Edição comemorativa de cinqüentenario de Universidade de São Paulo): 284.

Tixier, J. 1984, Escavaçoes no sitio de Ksar’Aqil, Libano. Resumo. Revista de pré-história Universidade de São Paulo. Institutto de Pré-historia, 6(Edição comemorativa de cinqüentenario de Universidade de São Paulo): 162.

Tixier, J. 1984, Estructuras falsas, estructuras masaradas e estruturas fantasmas na região de Khor, Qatar, Golfo Arabico. Resumo. Revista de pré-história - Universidade de São Paulo. Institutto de Pré-historia, 6(Edição comemorativa de cinqüentenario de Universidade de São Paulo): 207.

Tixier, J. 1984, Lames. In: Préhistoire de la Pierre Taillée, t. 2 : Économie du débitage laminaire, Cercle de Recherches et d'Études Préhistoriques, Paris: p. 13-19.

Tixier, J. 1984, Le débitage par pression. In: Préhistoire de la Pierre Taillée, t. 2 : Économie du débitage laminaire, Cercle de Recherches et d’Études Préhistoriques, Paris: p. 57-70. 
Tixier, J. 1984, Tecnologia litica: a contribuição das experiências de lascamento. Resumo. Revista de pré-história - Universidade de São Paulo. Institutto de Pré-historia, 6(Edição comemorativa de cinqüentenario de Universidade de São Paulo): 298.

Tixier, J. 1984a, Économie du débitage laminaire. Préhistoire de la pierre taillée Vol. 2. Cercle de Recherches et d'Études Préhistoriques, Paris, 166 p.

Tixier, J. 1986, The prehistory of the Gulf: recent finds. In: Bahrain through the ages (AlKhalifa, S.A.B.K. \& Rice, M., Eds.), KPI, London, New York, Sydney and Henley: p. NR OF PAGES.

Briard, J. \& Tixier, J. 1987, Approches technologiques des cultures préhistoriques. In: Images des sciences de l'homme (Panoff, M., Bordes, D., Courtin, J. \& Touzet, D., Eds.). Supplément au ${ }^{\circ} 67$ de La Recherche (C.N.R.S.), Centre National de la Recherche Scientifique, Paris: p. 85-88.

Hublin, J.-J., Tillier, A.-M. \& Tixier, J. 1987, L'humérus d'enfant moustérien (Homo 4) du Djebel Irhoud (Maroc) dans son contexte archéologique. Bulletins et Mémoires de la Société d'anthropologie de Paris, série XIV, 4(2): 115-141.

doi:10.3406/bmsap.1987.1625

Tixier, J., Buisson, L., Chalard, Y., Delbancut, O., Lacapere, S., Lacapere, J., Nicquevert, X., Paris, P., Prevel, A., Camps, G., Glory, A., Guérin, P., Lecourt, C., Lhote, H., Petard, J.M., Roffe, A., Roy, G., Gaillard, M.-F.o., Reduron, M. \& Vignau, M., (directors) 1988, La vie quotidienne des hommes préhistoriques. École Moderne, Mouans-Sartoux. audio cassette and brochure. URL: http://www.icemfreinet.net/ btj/H429preh/outiprson2.htm

Mellars, P. \& Tixier, J. 1989, Radiocarbon-accelerator dating of Ksar 'Aqil (Lebanon) and the chronology of the Upper Palaeolithic sequence in the Middle East. Antiquity, 63(1): 761-768. doi:10.1017/S0003598X00076894

Pélegrin, J. \& Tixier, J. 1990, Conclusions générales; Ve Symposium sur le silex, Section Technologie. In: Le silex de sa Genèse à l'Outil. Actes du Ve Colloque International sur le Silex (Séronie-Vivien, M.-R. \& Lenoir;, M., Eds.). Cahiers du quaternaire Vol. 17, Centre national de la recherche scientifique (CNRS), Paris: p. 603-604.

Reduron, M. \& Tixier, J. 1991, Cogitations non-conclusives. In: 25 ans d'études technologiques en Préhistoire: Bilan et perspectives. XIe Rencontres Internationales d'Archéologie et d'Histoire d'Antibes: Actes des rencontres 18-19-20 octobre 1990. Rencontres internationales d'archéologie et d'histoire d'Antibes Vol. 11, Édition Association pour la promotion et la diffusion des connaissances archéologiques (APDCA), Juan-les-Pins: p. 391-394.

Reduron-Ballinger, M. \& Tixier, J. 1991, Et passez au pays des silex: rapportez-nous des lames! In: 25 ans d'études technologiques en Préhistoire: Bilan et perspectives. XIe Rencontres Internationales d'Archéologie et d'Histoire d'Antibes: Actes des rencontres 18-19-20 octobre 1990. Rencontres internationales d'archéologie et d'histoire d'Antibes Vol. 11, Édition Association pour la promotion et la diffusion des connaissances archéologiques (APDCA), Juan-les Pins: p. 235-243.

Tillier, A.-M. \& Tixier, J. 1991, Une molaire d'enfant aurignacien a Ksar 'Aqil (Liban) Mt. Carmel, Israël. Paléorient, 17(1): 89-93. doi:10.3406/paleo.1991.4541

Tixier, J. 1991, Champ-Parel, Corbiac Vignoble 2 (CV2). In: Gallia Informations: Aquitaine (Rigaud, J.-P., Garmy, P., Bizot, B. \& Collier, A., Eds.), C.N.R.S, Paris: p. 8-10. 
Tixier, J. 1991, Cogitations non-conclusives. In: 25 ans d'études technologiques en Préhistoire. XIe Rencontres Internationales d'Archéologie et d'Histoire d'Antibes, Édition Association pour la promotion et la diffusion des connaissances archéologiques (APDCA), Juan-les Pins: p. 391-394.

Inizan, M.-L., Roche, H. \& Tixier, J. 1992, Technology of knapped stone. Préhistoire de la Pierre Taillée Vol. 3. Cercle de Recherches et d’Études Préhistoriques (C.R.E.P), Paris, $127 \mathrm{p}$.

Tixier, J. \& de Saint-Blanquat, H. 1992, Le biface, silex taillé; Voyage en préhistoire. Des objets font l'Histoire. Casterman, Tournai, $44 \mathrm{p} \mathrm{p.}$

Inizan, M.-L., Reduron-Ballinger, M., Roche, H. \& Tixier, J. 1995, Technologie de la pierre taillée : suivi par un vocabulaire multilingue allemand, anglais, arabe, espagnol, français, grec, italien, portugais. Préhistoire de la Pierre Taillée Vol. 4. Cercle de recherches et d'études préhistoriques (C.R.E.P), Meudon, 201 p.

Tixier, J. 1995, La notion de chaîne de travail: chaîne opératoire de son application à l'élaboration/construction de la recherche. Exposé. In: Carrefour des Métiers : Les Dessinateurs en Archéologie, Centre de Recherches Archéologiques du C.N.R.S, Paris: p. 11.

Tixier, J., Roe, D., Turq, A., Gibert, J., Martines, B., Arribas, A., Gibert, L., Gaete, R., Maillo, A. \& Iglesias, A. 1995, Présence d'industries lithiques dans le Pléistocène inférieur de la région d'Orce (Grenade, Espagne): Quel est l'état de la question? Compte-rendu Académie des Sciences de Paris série IIa, 321: 71-78.

Tixier, J. 1996, Technologie et typologie: dérives et sclérose. Quaternaria nova, 6: 15-21.

Inizan, M.-L., Roche, H. \& Tixier, J. 1998, 石器研究入門 (translated by Onuma, K., Nishiaki, Y. \& Suzuki, M.). クバプロ [Kuba Puro], Tokyo, 146 p. (in Japanese) ("Technology of Knapped Stone")

Inizan, M.-L., Reduron-Ballinger, M., Roche, H. \& Tixier, J. 1999, Technology and terminology of knapped stone: Followed by a multilingual vocabulary Arabic, English, French, German, Greek, Italian, Portuguese, Spanish (translated by Jehanne, F.-A.). Préhistoire de la pierre taillée Vol. 5. Cercle de Recherches et d'Études Préhistoriques (C.R.E.P), Nanterre, 193 p.

Lucas, G. 1999, Production expérimentale de lamelles torses : approche préliminaire. Bulletin de la Société préhistorique française, 96(2): 145-152. doi:10.3406/bspf.1999.10938

Tixier, J. 1999, Bordes François (1919-1981). In: Dictionnaire de la Préhistoire. Encyclopædia Universalis, Encyclopædia Universalis, Paris: p. 228-230.

Tixier, J. 1999, Expérimentation. (In: Lucas, G. Production expérimentale de lamelles torses : approche préliminaire. p. 145-152). Bulletin de la Société préhistorique française, 96(2): 146. doi:10.3406/bspf.1999.10938

Tixier, J. 1999, Taille expérimentale des roches dures. In: Dictionnaire de la Préhistoire. Encyclopadia Universalis, t. 13, Encyclopædia Universalis, Paris: p. 967-971.

Tixier, J. \& Turq, A. 1999, Kombewa et alii. Paléo, 11(1): 135-143. doi:10.3406/pal.1999.1174

Inizan, M.-L. \& Tixier, J. 2000, L'émergence des arts du feu : le traitement thermique des roches siliceuses. Paléorient, 26(2): 23-36. doi:10.3406/paleo.2000.4707 
Tixier, J. 2000, Outils moustériens à bulbe «piqueté » (Retaïmia, Algérie). In: À la recherche de l'Homme préhistorique (Mester, Z. \& Ringer, A., Eds.). Études et Recherches Archéologiques de l'Université de Liège (E.R.A.U.L.) Vol. 95, Service de Préhistoire Université, Liège: p. 125-130.

Tixier, J., Brugal, J.-P., Tillier, A.-M., Bružek, J. \& Hublin, J.-J. 2001, Irhoud 5, un fragment d'os coxal non adulte des niveaux moustériens marocains. Société Marocaine d'Archéologie et du Patrimoine, 1: 149-153.

Bordes, J.-G. \& Tixier, J. 2002, Sur l'unité de l'Aurignacien ancien dans le Sud-Ouest de la France : la production de lames et de lamelles. Espacio, Tiempo y Forma, Revista de la Facultad de Geografia e Historia, Serie I, 15: 175-194.

Hirth, G.H., Flenniken, J.J., Titmus, G.L. \& Tixier, J. 2003, Alternative Techniques for Producing Mesoamerican Style Pressure Flaking Patterns on Obsidian Bifaces. In: Mesoamerican Lithic Technology. Experimentation and Interpretation (Hirth, K.G., Ed.), The University of Utah Press, Salt Lake City: p. 147-152.

Tixier, J. 2003, Préface. In: Le Capsien typique et le Capsien supérieur, evolution ou contemporanéité? Les données technologiques (Rahmani, N., Ed.). Cambridge Monographs in African Archaeology Vol. 57; BAR International Series Vol. 1187, Archaeopress, Oxford.

Tixier, J. 2005, l'Homme préhistorique, le silex et le feu. Présentation et résumé de: Inizan, Marie-Louise et Tixier, Jacques (2001a). Prahistoria, 6: 47.

Tixier, J. 2005, Modules et torsitude. Préface. In: Productions lamellaires attribuées à l'Aurignacien, chaînes opératoires et perspectives techno-culturelles. Actes du XIVe congrès de l'Union Internationale des Sciences Préhistoriques, Liège 2001 (Le BrunRicalens, F., Bordes, J.-G. \& Bon, F., Eds.). Collection ArchéoLogiques Vol. 1, Musée National d'Histoire et d'Art, Luxembourg: p. 19-21.

Tixier, J. 2012, A Method for the Study of Stone Tools. Guideline based on the Work of J. Tixier / Méthode pour l'étude des outillages lithiques. Notice sur les travaux scientifiques de J. Tixier. Collection ArchéoLogiques, 4. Musée National d'Histoire et d'Art - Centre National de Recherche Archéologique, Luxembourg, 197 p.

Mester, Z. \& Tixier, J. 2013, Pot à lames: The Neolithic Blade Deposit from Boldogkőváralja (Northeast Hungary). In: Moments in time: Papers Presented to Pál Raczky on His 60th Birthday (Anders, A., Kulcsár, G., Kalla, G., Kiss, V. \& Szabó, G.V., Eds.). Prehistoric Studies Vol. 1, Ösrégészeti Társaság, Prehistoric Society, Eötvös Loránd University, Budapest: p. 173-185.

Rigaud, J.-P., Texier, P.-J. \& Turq, A., (directors) 2015, Jacques Tixier. Pôle International de la Préhistoire, Musée National de Préhistoire, Eyzies-de-Tayac. 24 digital videos interviews. URL: https://www.pole-prehistoire.com/index.php/fr/decouvrir/lesressources-en-ligne/expositions-virtuelles/90-portail-les-temoins-de-la-prehistoire/lestemoins-de-la-prehistoire/309-jacques-tixier 